\title{
Zasada demokratycznego państwa prawnego w orzecznictwie Trybunału Konstytucyjnego
}

- istoria Trybunału Konstytucyjnego sięga jeszcze przed rok 1989, gdyż orzekać zaczął on trzy lata wcześniej, a jego działalność orzecznicza, niemal od powstania, niezmiennie budzi wielkie zainteresowanie nie tylko wśród osób zajmujących się prawem. Z jednej bowiem strony, żywo zainteresowana rozstrzygnięciami w konkretnych kwestiach jest szeroka publiczność - tak było na przykład w przypadku ustawy lustracyjnej czy ustawy otwierającej dostęp do zawodów prawniczych ${ }^{1}$. $Z$ drugiej, co oczywiste, działalność Trybunału od jego zarania jest przedmiotem zainteresowania doktryny. Wydaje się jednak, iż żadna kwestia związana z jego orzecznictwem nie została otoczona taką ilością rozważań sekundarnych jak artykuł 2 Konstytucji RP.

Artykuł 2 Konstytucji Rzeczpospolitej Polskiej, która weszła w życie 2 kwietnia 1997 roku stanowi, że: „Rzeczpospolita Polska jest demokratycznym państwem prawnym, urzeczywistniającym zasady sprawiedliwości społecznej”. Choć sama koncepcja państwa prawnego znana była polskiej jurysprudencji dużo wcześniej, to charakteru normatywnego nabrała ona dopiero w 1989 roku, gdy nowelą uchwaloną 19 grudnia zasadę tę wprowadzono do konstytucji PRL-u z 1952 roku². Wydaje się, że istotnie owo jedno konstytucyjne zdanie stanowi koniunkcję dwóch lub trzech pomniejszych:

Odpowiednio: wyr. z dn. 11.05.2007, K 2/07; wyr. z dn. 08.11.2006, K 30/06.

Zob. Dz. U. z 1989 r. Nr 75, poz. 444. 
1. Rzeczpospolita Polska jest państwem demokratycznym, resp. 1) Rzeczpospolita Polska jest demokratycznym państwem prawnym; 2) Rzeczpospolita Polska jest państwem prawnym; 3) Rzeczpospolita Polska urzeczywistnia zasady sprawiedliwości społecznej. Ostatnia część tego członu doczekała się jednak znacznie mniejszego zainteresowania, stąd też to idea demokratycznego państwa prawnego będzie tu przedmiotem zainteresowania.

Sławomira Wronkowska wskazuje na to, iż w polskiej literaturze przedmiotu przytacza się co najmniej kilka możliwych interpretacji tego, jaki jest status przepisu wyrażającego normę z artykułu 2 Konstytucji. Można więc mówić o przynajmniej następujących rozwiązaniach problemu - jako klauzuli generalnej, jako przepisu odsyłającego lub blankietowego ${ }^{3}$. Jak wiadomo, nie wszystkie przepisy prawne wskazują wprost na pewne określone obowiązki lub uprawnienia, a przepisy blankietowe i odsyłające mają właśnie taki charakter. Te pierwsze wskazują na regulacje, które mają powstać, te drugie zaś odnoszą się do systemowych lub pozasystemowych unormowań danego zagadnienia ${ }^{4}$. Jeśli idzie o klauzulę generalną, pojęcie to nie zostało jednoznacznie określone w literaturze. Można jednak przyjąć, że jest ona „nieokreślonym znaczeniowo zwrotem języka prawnego, odsyłającym do ocennych i ogólnie ukierunkowanych kryteriów pozaprawnych, którego konkretna treść jest ustalana w procesie stosowania prawa"5. Wydaje się, iż słusznie argumentuje Wronkowska i sygnalizuje Morawski, że art. 2 Konstytucji zawiera odesłanie pozasystemowe, a odsyłać ma on do pewnej koncepcji demokratycznego państwa prawnego.

Niedługo po uchwaleniu nowelizacji grudniowej do poprzednio obowiązującej konstytucji, Trybunał rozpoczął swą linię orzeczniczą odnoszącą się do ówczesnego artykułu 1, a kontynuowaną na gruncie nowej ustawy zasadniczej. Od razu na początku TK wskazał na dwie możliwe interpretacje przepisu. W orzeczeniu z 8 maja 1990 pisze on, iż „obowiązkiem ustawodawcy jest takie stanowienie prawa, by nie naruszało ono ani zasady sprawiedliwości, ani zasady równości jako podstawowych praw konstytucyjnych obywateli"6. Zaś w orzeczeniu z 22 sierpnia tego samego roku, Trybunał orzekł, że „zasada niedziałania prawa wstecz jest jednym z istotnych elementów zasady państwa prawnego (art. 1 konstytucji). Wynikająca z zasady państwa

Zob. S. Wronkowska, Charakter prawny klauzuli demokratycznego państwa prawnego (art. 2 Konstytucji Rzeczypospolitej Polskiej), w: Zasada demokratycznego państwa prawnego w Konstytucji RP, red. S. Wronkowska, Warszawa 2006, s. 102 i nast.

Zob. L. Morawski, Wstęp do prawoznawstwa, Toruń 2006, s. 61-62.

L. Leszczyński, Klauzule generalne w stosowaniu prawa, Lublin 1986; cyt. za: I. Wróblewska, Zasada demokratycznego państwa prawnego w orzecznictwie Trybunału Konstytucyjnego, doktorat niepublikowany, s. 42.

6 Orz. z dn. 8.05.1990, K 1/90. 
prawnego zasada zaufania obywatela do państwa wymaga - zgodnie z dotychczasowym orzecznictwem Trybunału Konstytucyjnego - by nie «stanowić norm prawnych, które nakazywałyby stosować nowo ustanowione normy prawne do zdarzeń (rozumianych sensu largo), które miały miejsce przed wejściem w życie nowo ustanowionych norm prawnych i z którymi prawo nie wiązało dotąd skutków prawnych normami tymi przewidzianych»"”. Oba orzeczenia wyjściowo rysowały dwie moźliwe interpretacje zapisów art. 1 ówczesnej ustawy zasadniczej. Pierwsza, zwana materialną, pozwala TK na ocenę materialnych elementów ustawodawstwa, a więc, szerzej, na ocenę słuszności decyzji prawodawczych i w tym duchu przebiega więc odszukiwanie w krótkim konstytucyjnym zdaniu całego szeregu kolejnych i coraz to bardziej szczegółowych zasad materialnych. Natomiast druga koncepcja, formalna, sugeruje, iż wyrażenie „państwo prawne” kryje w sobie pewne zasady szczegółowe dotyczące stanowienia prawa; z niej wyprowadzono też zwartą linię orzeczniczą stanowiącą o tym, co zdaniem Trybunału jest przyzwoitą legislacją ${ }^{8}$. Linia demarkacyjna tego podziału nie jest jednak aż tak wyraźna, jak wydawać by się mogło prima facie. Nie ulega bowiem żadnym wątpliwościom, iż większość zasad, jakie TK wyimplikował z zasady demokratycznego państwa prawnego, ma odcienie charakterystyczne dla obu tych koncepcji, istotą wydaje się raczej kwestia proporcji'

Co zaś, jeśli idzie o pojęcie państwa prawnego, którym to, jak stanowi art. 2, ma być Rzeczpospolita Polska? Nie ma i nigdy nie było w polskiej i światowej literaturze jednej, zwartej i powszechnie podzielanej koncepcji państwa prawnego. Można mówić najdalej o dwóch zasadniczych typach, które wykształciły się na tle dwóch kultur - civil i common law, chodzi o niemiecką ideę Rechtsstaat i anglosaską the rule of law - w tym też sensie nie ma mowy o żadnym pros hen państwa prawnego i ewentualnych państwach prawnych secundum quit. Słusznie zauważa więc Morawski, że wbrew - być może dość szeroko podzielanemu - przekonaniu, iż idea państwa prawnego jest powszechna czy tym bardziej uniwersalna, to odnosi się ona jedynie do pewnego kręgu cywilizacyjnego, bo przecież brak jest realizacji tej idei na przykład w państwach islamskich ${ }^{10}$. Warto także przypomnieć, iż istnieje jako się rzekło w demokracjach zachodnich dość ugruntowany podział na praworządność formalną i materialną, gdzie ta pierwsza odwołuje się do

Orz. z dn. 22.08.1990, K 7/90.

8 Zob. L. Garlicki, Materialna interpretacja klauzuli demokratycznego państwa prawnego w orzecznictwie Trybunału Konstytucyjnego, w: Zasada demokratycznego państwa prawnego..., s. 125-126.

9 Zob. M. Kordela, Formalna interpretacja klauzuli demokratycznego państwa prawnego $w$ orzecznictwie Trybunału Konstytucyjnego, w: Zasada demokratycznego państwa prawnego..., s.141.

10 Zob. L. Morawski, Główne problemy współczesnej filozofii prawa, Warszawa 2005, s. 321. 
obowiązku przestrzegania prawa tylko dlatego, że zostało ono uchwalone zgodnie z obowiązującymi zasadami, natomiast koncepcja materialna odnosi się do szerszego kontekstu okoliczności pozaformalnych, do zgodności prawa $\mathrm{z}$ określonymi wartościami materialnymi ${ }^{11}$. Słusznie argumentuje Morawski, iż podział ów opiera się na kilku błędach. Sam więc wskazuje na następujące warunki istnienia państwa prawa: na poziomie politycznym większościowe prawo obywateli do wyboru ustroju, gwarancja formalna i faktyczna dla legalnie działającej opozycji oraz pokojowa zmiana rządzących; na poziomie społecznym - elementarne prawa i wolności obywateli, wolność słowa i zrzeszania jako podstawa ustroju; na poziomie ekonomicznym - własność prywatna i wolny rynek podstawą systemu ekonomiczne$\mathrm{go}^{12}$. Także John Finnis, wskazując na podstawowe elementy rządów prawa, podkreśla, że w koncepcji tej zogniskowane są warunki formalne z wymaganiami sprawiedliwości i dobra wspólnego. Jego zdaniem, system prawny w państwie prawa charakteryzują następujące cechy: jego normy są prospektywne; nie ma żadnej przeszkody wynikającej z ich właściwości, która uniemożliwiałaby podporządkowanie się im; są jasne; zostały ogłoszone; system, który wspólnie tworzą jest spójny; dzięki ich trwałości ludzie mogą kierować się znajomością ich treści; nawet w sytuacjach, wymagających wydania dekretu czy rozporządzeń regulujących, wydanie to wynika z nadrzędnych norm o cechach trwałości, jasności i ogólności; ludzie, którzy tworzą i stosują normy oceniani są pod kątem tego czy przestrzegają odpowiednich zasad i czy prawo jest przez nich stosowane konsekwentnie, w zgodzie z jego sensem. Finnis podkreśla też, że idea Rechtsstaat jest jednym z aspektów idei rządów prawa ${ }^{13}$. Właśnie na niemiecką ideę państwa prawnego (Rechtsstaat) wskazuje się najczęściej jako na źródło, z którego czerpał polski ustawodawca przy okazji tworzenia tekstu konstytucji. Wynika to jasno $\mathrm{z}$ historii obrad nad projektem w Komisji Ustawodawczej, a potem także, choć może nie zawsze jednoznacznie, z późniejszej linii orzeczniczej samego Trybunału Konstytucyjnego ${ }^{14}$. Przyjęcie jednej z perspektyw teoretycznych - praworządności formalnej lub materialnej, ma kluczowe znaczenie dla praktyki życia społecznego. Widać to było wyraźnie zaraz po zakończeniu II wojny światowej, gdy w Norymberdze sądzono zbrodniarzy hitlerowskich, którzy przecież nie robili nic więcej oprócz realizacji rozkazów wydanych w zgodzie z obowiązującym ówcześnie prawem. Należało sobie wtedy odpowiedzieć na pytanie:

\footnotetext{
Morawski wskazuje też na błędność tego podziału. Zob. tamże, s. 318.

Zob. tamże, s. 322.

Zob. J. Finnis, Prawo naturalne i uprawnienia naturalne, Warszawa 2001, s. 304 i nast.

Zob. E. Morawska, Klauzula państwa prawnego w Konstytucji RP na tle orzecznictwa Trybunatu Konstytucyjnego, s. 53.
} 
czy do tego, by prawo obowiązywało wystarczy, by uchwalono je zgodnie z wymogami formalnymi, czy też winno być ono też nośnikiem przynajmniej elementarnych wartości? Wtedy też przeciwstawiono ponadustawowe prawo ustawowemu bezprawiu, a kwestie te na powrót stały się przedmiotem zainteresowania - i w Niemczech po upadku Muru Berlińskiego, i w Polsce po 1989 roku, gdy należało ustosunkować się do czynów popełnionych przed przemianą ustrojową, zgodnych z poprzednio obowiązującym prawem, ale trudnych do obrony na poziomie aksjologicznym ${ }^{15}$.

Podkreślenia wymaga fakt, iż już w czasach III Rzeczpospolitej w orzecznictwie Trybunału Konstytucyjnego musiała nastąpić zmiana. Wraz $\mathrm{z}$ nowelą grudniową $\mathrm{w}$ polskim porządku prawnym pojawił się postulat demokratycznego państwa prawnego, realizującego zasady sprawiedliwości społecznej. Wprowadzono, co prawda, do poprzedniej ustawy zasadniczej także szereg innych zmian, jednak były one niewystarczające, stąd ówczesny art. 1 musiał stać się samoistnym źródłem wielu praw i wolności, które nie zostały explicite w konstytucji wymienione. Na ten temat wypowiedział się też sam Trybunał, wskazując, iż „po wejściu w życie konstytucji zmienił się zakres treściowy zasady państwa prawa, wyrażonej wcześniej $w$ art. 1 pozostawionych w mocy przepisów konstytucyjnych. Wiele zasad, dawniej objętych treścią art. 1, znalazło swój wyraz w odrębnych przepisach ustawy zasadniczej z 2 kwietnia 1997 r. Dlatego art. 2 konstytucji, statuujący zasadę państwa prawa, przestał odgrywać rolę «uniwersalnego punktu odniesienia przy badaniu konstytucyjności» (L. Garlicki, Orzecznictwo Trybunału Konstytucyjnego, PS 1999 r., Nr 6, s. 122)"16. Jednak mimo tego, że szereg kwestii uprzednio wyprowadzanych przez TK z artykułu 1 - wyrażono wprost w nowej Ustawie, to pozycja aktualnego artykułu 2 nie uległa osłabieniu. Wciąż jest on dla sędziów Trybunału źródłem wielu zasad, których expressis verbis $\mathrm{w}$ tekście konstytucji nie da się odnaleźć. Jeśli idzie o stosunek do wcześniejszego dorobku orzeczniczego, to na ten temat TK wypowiedział się w wyroku z 25 listopada 1997 roku: ,[...] zasada demokratycznego państwa prawnego nie tylko znalazła wyraz w nowej konstytucji, ale też, że sformułowanie art. 2 jest dosłownym powtórzeniem dawnego art. 1 przepisów konstytucyjnych, wprowadzonego do naszego porządku konstytucyjnego [...] już w nowym porządku ustrojowym. Konwencję redakcyjną polegającą na dosłownym powtórzeniu przepisu należy uznać za jasny wyraz intencji ustawodawcy konstytucyjnego do przejęcia dotychczasowego kształtu i rozu-

15 Zob. M. Kordela, „Lex” $i$ „Ius” w orzecznictwie Trybunału Konstytucyjnego, „Ius et Lex” 2002, nr 1 , s. 216 i nast.

16 Wyr. z dn. 12.04.2000, K 8/98. 
mienia zasady demokratycznego państwa prawnego, tak jak się ona uformowała w praktyce konstytucyjnej, a zwłaszcza w orzecznictwie minionych ośmiu lat. Identyczności językowej towarzyszy bowiem bliskość aksjologiczna - zespół wartości, który legł u podstaw nowelizacji grudniowej z $1989 \mathrm{r}$. znalazł potwierdzenie i rozwinięcie w konstytucji z 2 kwietnia 1997. Tym samym, podstawowa treść zasady demokratycznego państwa prawnego wyrażonej w art. 2 konstytucji, może i powinna być rozumiana w taki sam sposób, jak rozumiano treść tej zasady w poprzednim porządku konstytucyjnym. Modyfikacje owego rozumienia mogą oczywiście wynikać zarówno z konkretnych unormowań nowej konstytucji, jak z ogólnego kontekstu jej postanowień, dopóki jednak nie zostanie zademonstrowane, że modyfikacje takie nastąpiły, można zakładać aktualność dotychczasowych ustaleń i konstrukcji dotyczących zasady demokratycznego państwa prawnego"17. Zgodnie z deklaracją wyrażoną od razu po uchwaleniu nowej konstytucji, Trybunał, zważając na wyrażone - teraz już wprost - przez ustawodawcę normy nowych przepisów ustawy zasadniczej, konsekwentnie kontynuował podjętą na gruncie noweli grudniowej linię orzeczniczą. Najistotniejszą zmianą, jaka miała miejsce wraz z wprowadzeniem do porządku prawnego nowej konstytucji, jest fakt, iż w zasadzie zamknęła ona drogę do wyprowadzania z zasady demokratycznego państwa prawnego zasad powyżej opisywanych jako materialne. Taka interpretacja bowiem czyniłaby zbędnymi artykuły 31 ust. 2, 38, 45, 47 i 51 konstytucji. Skoro też ustawa zawiera już w swym tekście zasady wyrażone wprost, to nie ma potrzeby odwoływania się do przepisu zawierającego unormowanie o najwyższym stopniu ogólności. Nie jest to jednak droga zamknięta, co wynika z nierozwiązywalnego i w jakimś sensie jałowego sporu o rozdział zasad na materialne i formalne ${ }^{18}$. Trybunał Konstytucyjny nie zezwala jednak na wnioskowanie a contrario z faktu, iż niektóre spośród zasad wcześniej zinterpretowanych teraz wprost pojawiły się w przepisach: „W żadnym razie nie może to jednak dawać podstawy [...] do twierdzenia, że skoro wiele zasad i reguł dawniej wyprowadzanych z klauzuli demokratycznego państwa prawnego, znalazło obecnie wyraz w szczegółowych przepisach konstytucji, to pominięcie w tych przepisach innych zasad i reguł daje wyraz intencji ustawodawcy konstytucyjnego do pozbawienia ich rangi konstytucyjnej" ${ }^{\prime 1}$. Argumentacja w tej materii wydaje się jak najbardziej słuszna, bowiem zastosowanie w tym wypadku wnioskowania a contrario stałoby się naruszeniem innej z dyrektyw wykładni -per non est. Gdyby

\footnotetext{
Wyr. z dn. 25.11.1997, K 26/97.

Zob. I. Wróblewska, dz. cyt., s. 51.

Wyr. z dn. 13.04.1999, K 36/98.
} 
bowiem przyjąć rozumowanie odwrotne, wówczas zapis artykułu 2 mógłby zostać uznany za zbędny.

Z wykładnią konstytucji dokonywaną w szerokim orzecznictwie Trybunału łączy się też szereg niezwykle ważkich pytań innego rodzaju. Sam TK przecież wskazuje, iż „dokonując wykładni przepisów, uwzględnia podobnie jak inne sądy ich kontekst językowy, systemowy, społeczny, aksjologiczny oraz cel przepisów [...] W orzecznictwie Trybunału Konstytucyjnego szczególne znaczenie odgrywa kontekst aksjologiczny. Biorąc bowiem pod uwage kontekst systemowy, obowiązany jest on szczególnie mieć na uwadze przepisy konstytucyjne, które w stopniu znacznie silniejszym niż inne przepisy nawiązują do wartości, jakimi kieruje się społeczeństwo. Ale nie tylko wartości wypowiedziane w przepisach konstytucyjnych są wskazówką dla Trybunału. Regulacje te nie zawsze określają w sposób zupełny te wartości, które stały się drogowskazem dla ustawodawcy. Stąd, Trybunał Konstytucyjny, dokonując wykładni przepisów, obowiązany jest brać również pod uwagę wartości, które jeszcze nie zostały wypowiedziane bezpośrednio w przepisach konstytucyjnych"20. Trybunał z wielką łatwością porusza się pomiędzy dyrektywami wykładni językowej, a systemowej czy, a może i przede wszystkim, funkcjonalnej. W końcu, otwarte pozostają pytania o to, czy istnieje w ogóle jakakolwiek spójna teoria wykładni leżąca u podstaw orzecznictwa konstytucyjnego w Polsce ${ }^{21}$. Przede wszystkim jednak, problematyczna pozostaje kwestia tego, jak zapatrywać się na działalność Trybunału, której można przypisać cechy prawotwórstwa. Choć bowiem w przytoczonym powyżej orzeczeniu TK mówi dalej o tym, iż w swej wykładni niczego nie dodaje i nie ujmuje do systemu obowiązujących norm prawnych, to trudno oprzeć się wrażeniu, iż stwierdzenie to niekoniecznie odpowiada rzeczywistości i że uzasadnienie stojące za tym, w jaki sposób przebiega owo wyprowadzanie jednych norm $z$ drugich niekoniecznie jest przekonywujące. Nie ulega wątpliwości, iż katalog dyrektyw wykładni nie jest ani zamknięty, ani bezwzględnie uporządkowany. Mają one raczej charakter racji na rzecz lub przeciw jakiejś interpretacji, co zasadniczo zgadza się z retoryczno-topiczną wizją wykładni Chaima Perelmana i z retoryką w formie, o jakiej pisał już Arystoteles, czyli „umiejętności metodycznego odkrywania tego, co w odniesieniu do każdego przedmiotu może być przekonywające"22. Jeśli przyjąć taką wizję procesu wykładni, to wnioskowania Trybunału Konstytucyjnego wyprowadzające z zasady demokratycznego państwa prawnego każdą kolej-

20 Uchwała z dn. 07.03.1995, W 9/94.

21 Zob. T. Gizbert-Studnicki, Teoria wykładni Trybunału Konstytucyjnego, w: Teoria prawa. Filozofia prawa. Wspótczesne państwo i prawoznawstwo, Toruń 1998, s. 75.

22 Arystoteles, Retoryka, 1355 b. 
ną zasadę będą przekonywujące tym bardziej, im lepiej będzie on w stanie takie orzeczenia uzasadnić, odwołując się jednak do szerokiego kontekstu pozaprawnego, a więc do pewnej określonej wizji państwa prawnego. Innymi słowy, im lepiej przedstawi on racje, które stały za przyjęciem takiej a nie innej interpretacji przepisu i skorzystaniem $\mathrm{z}$ takich a nie innych dyrektyw interpretacyjnych, z tym większym zrozumieniem spotkają się przyjęte przez niego interpretacje. Jednak wymaga podkreślenia, że żadne ujęcie dyrektyw wykładni nie anuluje ciągle aktualnego pytania o prawotwórczy charakter interpretacji dokonywanych przez Trybunał. Jest jasne, że sędziowie, szczególnie jeśli idzie o sądownictwo konstytucyjne, przestali być tylko „ustami ustawy”, jak tego dawniej chcieli pozytywiści. Wydaje się także, iż taki idealny typ orzekania nie jest w ogóle możliwy w pluralistycznych, zorientowanych na prawa jednostki demokracjach. Tym dziwniejsze zdają się uparte deklaracje samego Trybunału Konstytucyjnego, iż jego działania mają charakter odtwórczy.

W jaki więc sposób Trybunał z zasady demokratycznego państwa prawnego realizującego zasady sprawiedliwości społecznej wyprowadza szereg kolejnych zasad coraz to bardziej szczegółowych? W jaki sposób przepis, którego treść jest tak lakoniczna, stał się punktem wyjścia dla sporej liczby zasad, o znaczeniu przecież rudymentarnym dla obywateli? Jakie to logiczne rozumowanie leży u podstaw wykoncypowania z kilku słów „takiego ogromu zasad [...] a przy tym uzasadnieniu tak wielu wyjątków od nich"23? Wnioskowanie używane przez Trybunał Konstytucyjny nazywa się wnioskowaniem z normy o normie. W praktyce polega ono na tym, iż uznaje się, iż istnieje związek logiczny (wynikanie?) i instrumentalny między zasadą demokratycznego państwa prawnego a innymi zasadami z niej wyprowadzanymi; a więc zasady szczegółowe państwa prawnego mają być „umocowane” w innej normie wprost wyrażonej w tekście konstytucji. Należy jednak dodać, że orzecznictwo Trybunału nie kończy się na wyprowadzaniu zasad ogólnych $\mathrm{z}$ artykułu 2, a wcześniej 1 ustawy zasadniczej, bowiem z owych zasad ogólnych wyprowadza też kolejne, o coraz mniejszym poziomie ogólności. Takie dwustopniowe wnioskowanie inferencyjne stało się na przykład podstawą do wyimplikowania z zasady ochrony zaufania obywateli do państwa i stanowionego przez nie prawa kolejnej zasady - ochrony praw słusznie nabytych. Trybunał Konstytucyjny uznał wreszcie, iż normy wywiedzione przez niego w taki sposób z zasady demokratycznego państwa prawnego, mogą stać się

23 L. Morawski, Spór o pojęcie państwa prawnego, PiP 1994, nr 4, s.12. 
samoistną podstawą orzekania o zgodności z ustawą zasadniczą innych aktów normatywnych ${ }^{24}$.

Istnieje więc cała rzesza zasad, które krętymi ścieżkami zostały przez Trybunał wyprowadzone z zasady demokratycznego państwa prawnego. Metafora ta wskazuje jasno na to, iż skoro da się z artykułu 2 Konstytucji coś wyprowadzić, to drogą prowadzącą w przeciwnym kierunku da się też coś odtworzyć, stąd wszystkie te zasady szczegółowe składają się wspólnie na wizję państwa prawnego przyjętą $\mathrm{w}$ polskim orzecznictwie konstytucyjnym. Jednak prawda jest taka, iż ustalenie tego, jakie są zależności pomiędzy poszczególnymi zasadami szczegółowymi, a także tego, jak mają się one do zasady, z której same są wywiedzione, a wreszcie jak przedstawia się ich treść normatywna - jest niezwykle trudne, by nie powiedzieć, że może być po prostu niemożliwe ${ }^{25}$. I choć, jak wspomniano, uchwalenie nowej konstytucji „ukróciło” nieco działalność Trybunału, w której można się doszukać cech prawotwórczych, to jednak katalog tego, co odnaleziono w przepisie mówiącym o demokratycznym państwie prawnym pozostaje imponujący. Expressis verbis wyrażona została w nowej konstytucji część zasad kwalifikowanych jako materialne, a więc regulujących kwestie związane z prawami i wolnościami jednostki, a które wcześniej wyprowadzane były z demokratycznego państwa prawnego, czyli: prawo do życia, prawo do prywatności, prawo do ochrony godności, prawo do sądu, prawo jednostki do ochrony danych osobowych. Spośród tak zwanych zasad formalnych explicite wyrażono na przykład zasady odnoszące się do proporcjonalności (choć nie w pełnym rozumieniu tej zasady), zakaz retroaktywnego działania prawa czy kwestię odpowiedniego vacatio legis ${ }^{26}$.

Katalog zasad, jakie Trybunał Konstytucyjny wyprowadził z zasady demokratycznego państwa prawnego, jest niezwykle rozbudowany i, zgodnie z powyższymi informacjami o charakterze wywodzenia norm, wielostopniowy. I tak zaliczyć do nich należy: zasadę zaufania obywateli do państwa i stanowionego przez nie prawa, zasadę bezpieczeństwa prawnego (pewności prawa), ochrony praw słusznie nabytych, lex retro non agit, nullum crimen sine lege, zachowania odpowiedniej vacatio legis, zabezpieczania interesów w toku, pacta sunt servanda, ustawowej określoności przepisów prawa, wyłączności ustawowej formy dla praw i wolności a także prawa daninowego, zakaz wprowadzania unormowań mających wyłącznie iluzoryczny charakter, ne bis de idem w prawie karnym, zasadę równorzędności podmiotów

24 Zob. E. Morawska, dz. cyt., s. 205 i nast.

25 Zob. J. Mikołajewicz, Pojmowanie „państwa prawnego” w orzecznictwie Trybunału Konstytucyjnego, w: Polskie dyskusje o państwie prawa, red. S. Wronkowska, s.101.

26 Zob. I. Wróblewska, dz. cyt., s.49. 


\section{RP}

obrotu cywilnoprawnego, zakaz tworzenia instytucji publicznej, która uniemożliwiałaby jej rzetelne lub sprawne działanie. Wielostopniowość wyprowadzania zasad wskazuje na przykład na to, iż na zasadę bezpieczeństwa prawnego składają się kwestie stabilności, jasności i jawności prawa. Zasada zaufania obywateli do państwa i stanowionego przez nie prawa jest podstawą dla zasady ochrony praw słusznie nabytych, a one zaś składają się z zasady ochrony własności i zakazu retroaktywnego działania prawa. Duża część spośród przytoczonych tu zasad należy do zbioru zwanego zasadami poprawnej legislacji, podzielonych na te odnoszące się do techniki legislacyjnej $\mathrm{i}$ te, które są związane z wymogiem zagwarantowania ochrony zaufania obywateli do państwa i stanowionego przezeń prawa ${ }^{27}$.

Zasada demokratycznego państwa prawnego, wprowadzona do polskiej konstytucji od razu po zmianie porządku politycznego, przez wiele lat była dla Trybunału Konstytucyjnego niewyczerpywalnym źródłem, które sprawiło, iż dorobek TK pozostaje nieoceniony dla umocnienia zasad państwa demokratycznego w nowej rzeczywistości politycznej. Z drugiej jednak strony, należy postawić sobie pytanie o to, gdzie są granice dla wywodzenia kolejnych zasad z normy wyrażonej w jednym zdaniu ustawy zasadniczej. Być może faktycznie usprawiedliwianie środków celami było, jest i będzie zawsze uzasadnieniem dla takiej linii orzeczniczej, jednak i w takiej perspektywie pozostaje cały szereg pytań, które wymagają postawienia, są szeroko dyskutowane w doktrynie i nadają się na kolejne opracowania - a odnoszą się przede wszystkim do kwestii aktywizmu sędziowskiego.

A G A T A M I E T E K 


\section{Abstract}

The article The Democratic Rule of Law and the Constitutional Tribunal Jurisdiction is a short study of main aspects of Constitutional Tribunal Jurisdiction on the principles associated with the rule of law. Author presents how the rule was incorporated into the Polish legal system after the 1989 legal change and how it has been interpreting (formal and substantive interpretation) by the Constitutional Tribunal since then.

There are at least two main types of interpretation of this problem that has been evolving on the basis of two separate legal systems - civil and common law. It is German idea of the Rechtsstaat and Anglo-Saxon the rule of law. That is the general reason why examples of pros hen and secundum quit of such states cannot be found. Author describes two conceptions: Lech Morawaski's who specifies what does exactly the rule of law mean on separate levels of state and society and John Finnis' principles that must be guaranteed by a states and societies. According to Lech Morawski those standards are: on the political level - majority of citizens' right to choose political system, formal and actual guaranty for legal opposition and peaceful changes of governments. On the social level: basic civil rights and liberties, freedom of speech and organising as a basis of political system. On the economical level: private property and free market as a basis of economical system. Also John Finnis formulated guidelines that can be associated with all rule of law states. According to him such legal system must have following characteristics: its legal norms are prospective rather than retroactive; there are no internal obstacles that would make obeying them impossible; norms are clear and they must be published; legal system is coherent; norms are not to be changed frequently and citizens can trust that they know the law; even when it is necessary to edit some extraordinary laws they are based on stable, clear and general ones; those who make laws as well as those who apply it are controlled. Finnis claims that the idea of Rechtsstaat is an aspect of the rule of law. 